\title{
Exploring the Influencing Factors of Undergraduates' Continuance Intentions in e-Reading APPs (EIFUCIEA)
}

\author{
Wenqian Lai and Li Zhao
}

\begin{abstract}
Electronic reading (e-reading) becomes a common way of reading for undergraduates. Many e-reading applications (APPs) are designed to satisfy the readers' reading needs. But there is no such a study focus on using expectancy confirmation theory to examine undergraduates' continuance intentions (UCI) of reading APPs. Then to address this gap, this study was to investigate the influencing factors of UCI of reading APPs in a Chinese university. Based upon the EECM-IT model and DeLong \&McLean (D\&M) information system success model, the variables of Subjective Norm (SN) and Perceived Risk (PR) were introduced to the UCI model of e-reading and twelve hypotheses were proposed. The study adopted the confirmatory factor analysis method to examine the structural model. From data analysis, the results showed that undergraduates' expected confirmation of e-reading APPs was significantly affected by subjective norms, and significantly affected perceived ease of use, perceived risk, reading usefulness and user's satisfaction. However, satisfaction was not significantly affected by perceived risk and perceived ease of use. Subjective norms did not significantly affect continuance intentions. Additionally, there was no gender or grade difference among undergraduates' continuance intentions, which was only significantly related to their majors.
\end{abstract}

Index Terms-Influencing factors, undergraduates' continuance intention (UCI), e-reading APPs, e-book.

\section{INTRODUCTION}

Undergraduates are increasingly inclined to acquire knowledge and information through mobile devices such as mobile phones and tablet computers, and gradually shift from traditional paper reading to electronic reading (e-reading) [1]. The e-reading APPs can meet readers' needs of reading in their spare time and become an important tool of reading behaviors on mobile devices such as mobile phones [2]. Undergraduates are one of the main users of e-reading apps. E-reading APPs have won the favor of undergraduates with their powerful functions, convenience and interactivity. However, with the emergence of various types of e-reading APPs, undergraduates have difficulties to choose an appropriate e-reading APP. What factors affect undergraduates to make a good choice and continuance intention to adapt e-reading APPs is still not certain in recent studies. Thus, it is necessary to explore factors influencing

Manuscript received July 30, 2019; revised October 3, 2019. This work was supported in part by the Collaborative Innovation Center for Talent Cultivating Mode in Basic Education; and the Priority Academic Program Development of Jiangsu Higher Education Institutions in China.

The authors are with Nanjing Normal University, Nanjing, China (corresponding author: Li Zhao; e-mail: 903995084@qq.com, 20190231@qq.com). intentions of e-reading APPs that can help APPs designers and developers improve undergraduates' reading efficiency, make them feel satisfied and keep using the APPs.

In regarding reading efficiency, this study adapted perceived ease of use and usefulness from D\&M information system success model [3]. Similar as e-learning programs including a number of distinct courses and involving other delivery- and pedagogical aspects, exploring the total reading services that support undergraduates' aims to achieve their reading goals, the study uses the D\&M [4] to describe the success of the e-reading APPs from the undergraduates' perspective. Thus, we combined with the characteristics of e-reading and undergraduates' learner characteristics from the perspective of undergraduates in perceiving risk and subjective norm affecting undergraduates' reading and e-reading APPs.

To understand the satisfaction with e-reading APPs, this study applied the expectancy confirmation theory to design the research model. Relevant studies have been widely undertaken based on expectancy confirmation model Alraimi, Zo and Ciganek (2015) [5] and Huang (2019) [6] had highlighted the importance of investigating the factors behind students' continued use of educational technologies, which could be applied to supporting the application of these technologies. In addition, Huang (2017) [7] carried out the investigation into students' continued use of educational technologies not only serves as a critical indicator for the value of novel technologies, but also uncovers whether they can satisfy students' needs for learning. Huang (2017) [7], Liu and Huang (2015) [8] proposed the results of studies based on expectancy confirmation model had instructed teachers to bring the benefits of new technologies to students and helped developers bridge the gap between their design and usage. However, seldom study has been focused on satisfied with e-reading system. To address this gap, we require to systematically investigate students' continued use of e-reading services to explore the strengths, and the results will in turn promote their development.

In short, this study drew on expanding D\&M information system success model and the expectancy confirmation model to explore students' satisfaction with the information systems that influence their continuance intention to e-reading.

\section{LITERATURE REVIEW}

\section{A. E-Books and e-Reading Applications}

The emergence of electronic books (e-books) has changed 
people's reading habits and learning methods. The e-book also called digital book is the modern version of the book which has the same attributes of storing and disseminating information as a printed book, but in different format [1]. E-book is composed of reading software (program) and hardware (physical part), being able to display amounts of information and allowing navigation in a fast and practical way [9]. According the definition, e-reader was invented as a e-book hardware. E-reader, also knew as e-book reader or handheld reader, is an electronic device designed to read digital books and magazines [10]. On November 19th amazon, America's biggest e-commerce firm, launched its Kindle, which sold out within six hours, ushering in a new era of rapid growth for e-readers. The popularity of e-reading tools promotes the development of e-books, such as kindle. The success of kindle enables amazon to successfully integrate reading device (kindle), content (e-book) and service platform (amazon) [11]. Nowadays, e-readers have been transformed to e-reading APPs, such as JDRead and iReader. Kindle also has its online application. Without the device of Kindle, readers can download Kindle APP on their mobile devices to read e-books.

Furthermore, with the technology of Virtual Reality (VR), users can use the touch controls on the headset to select shows or movies in virtual reality environment and watch them. Dustin and Blake (2018) [12] started developing APPs for reading easily in Virtual Reality (VR) environments. As the world's first VR e-reader, Chimera Reader is now available on multiple platforms and devices in the United States and China. Users can easily read e-books anywhere in a comfortable and private environment.

E-books were thought to overcome some of the limitations of printed books while increasing students' interest and reading time [13]. Compared with traditional printed books, e-books were more durable, environmentally friendly and less likely to be damaged. Sanford (2013) [14] believed that the acceptance of e-books was increasingly high in the academic environment, and e-books could be a substitute for paper books, so as to stop using paper books and paintings. Although there are some studies focusing on the application of e-reading, but seldom research related to university students for their attitude, satisfaction and continuance intention of using e-reading APPs. Thus, the emphasis of this study was on exploring the influencing factors of undergraduates' continuance intentions in e-reading APPs.

\section{B. Expectation-Confirmation Model in the Context of e-Reading}

The theory of expectation confirmation was first proposed by Oliver (1980) [15] and had been widely used to study the behavior of users after purchase. In recent years, the theory of expectation confirmation has been applied by many scholars to the research on the repurchase of user products or the continuous use of various platforms. Bhattacherjee (2001) [16], based on the classical expectancy confirmation theory (ECT), integrated the technology acceptance model (TAM) and proposed a research model (ECM-IT) suitable for information system users' willingness to continue using.
After that, Thong, Hong and Tam (2006) [17] summarized previous studies to expand the willingness model of IT continuous use and put forward the EECM-IT model. Zhou (2017) [18] took the extended expectancy confirmation model (ECM) as the theoretical basis to explore the factors influencing online collaborative learning sustainability of mooc learners. The empirical results showed that the satisfaction of previous learning experience, the confirmation of previous learning experience and perceived usefulness had significant effects on the willingness to continue using. Tam, Santos and Oliveira (2018) [19] based on the expectation-confirmation model (ECM) and extended unified theory of acceptance and use of technology (UTAUT2), discussed the factors of the willingness to continue using mobile applications, and found that the most important factors of the continuance intentions using mobile applications were satisfaction and confirmation expectation.

Compared with the EMC-IT model, the fact of the perceived ease of use of information system was added in the extended expectation confirmation model. Perceived ease of use not only had a significant impact on perceived usefulness, but also directly affected users' satisfaction after use and their willingness to continue using the information system. Although, there are some studies concern how users are satisfied with some application, seldom research related to university students for their real thoughts on readers. Thus, this study focused on the importance of perceived usefulness, expected validation, and satisfaction in e-reading from student's perspective.

\section{DeLong \& McLean Information System Success Model in the Context of e-Reading}

The e-reading APP is a kind of book carrier that integrates man-machine interaction and interpersonal interaction with mobile devices. Therefore, readers' recognition of e-reading APP will not only be limited to the book content, but also be affected by system quality and service quality. Therefore, in this study, D\&M information system success model was integrated. In 1992, American scholars Delone and Mclean first proposed and carried out the modified annual information system success model based on the summary of previous research results. At present, the successful model of D\&M information system has widely applied or extended in various fields, and empirical research was carried out based on it.

Scholars usually integrated D\&M information system success model with other theoretical models to form new models, such as technology acceptance model, expectation confirmation model, planned behavior theory and trust theory. Balaban et al. (2013) [20] developed a tool to evaluate the electronic portfolio, and based on the information system success model of DeLone and McLean as the theoretical framework, constructed the corresponding ePortfolio success model, and helped to improve the implementation and use of ePortfolio system by analyzing the causal relationship between their different dimensions.

When Mohammadi (2015) [21] studied e-learning systems, he found that system quality and information quality had a 
greater impact on user satisfaction, and the continuance intentions had a positive and significant impact on behavior. For example, Aldholay et al. (2018) [22] investigated the adoption and use of online learning in different environments using the D\&M success model, and analyzed the data of 448 students from 9 public universities in Yemen. Although, there were some studies focusing on perceived ease of use and usefulness of e-reading, seldom research related to university students for system quality, information quality and service quality of e-readers. Therefore, this study adds perceived usefulness to the e-reading model to understand the extent to which the overall quality of students' e-reading influences their use.

\section{Research Model and Hypotheses}

Based on related studies and theoretical discussion, this study combined the EECM - IT and information system success model (DM). Two latent variables of subjective norm $(\mathrm{SN})$ and perceived risk (PR) were introduced into the research model, as shown in Fig. 1. In the research model, the four potential variables that jointly determine reading satisfaction (RS) are reading usefulness (RU), system usability (PEOU), expectation confirmation (EC) and perceived risk (PR). Reading usefulness, system usability and perceived risk are affected by expected confirmation. Continuance intention (CI) depends on user satisfaction and subjective norms. Orji (2010) [23] used UTAUT model to study the regulating effect of gender and nationality on users' continuance intentions, and found that it was more obvious among male international students. Pi and Sangruang (2011) [24] adopted the modified innovation diffusion theory to explore Chinese portal websites, and the empirical results showed that each innovation feature (compatibility, comparative advantage, complexity and playability) significantly affected the continuous use intention of adopters. The male were more susceptible to the influence of comparative advantage than the female, while the female were more susceptible to the influence of playability than the male.

Pinto et al. (2014) [25] presented the usage, habits and views of Spanish higher education students in reading on new digital media, and showed the potential future of e-books and reading mobile devices in academia. Experiments showed that students majoring in humanities, social sciences and law were more likely to read traditional printed books, while students majoring in experimental science, health and technology were more likely to read e-books. Students' preferences would be determined by their previous reading experience. Therefore, based on the characteristics of e-reading and undergraduates as a special group, majors, genders and grades were selected as moderating variables in this study.

Reading usefulness, users' satisfaction, and continuance intentions

Perceived usefulness refers to the degree that users can perceive improving their work performance after using a particular system [26]. In many researches, perceived usefulness can directly and positively affect users' satisfaction with information system. What deserves our attention is that Basnet et al.(2018) [27] found that perceived usefulness was a better predictor of learners' continuance intentions than satisfaction in the course of studying how to teach programming concepts based on the expected confirmation model. In this study, reading usefulness refers to the learners believe that e-reading APP can meet their reading needs and improve and motivate their reading efficiency and interests.

Satisfaction was initially applied to research in the field of marketing. If consumers were more satisfied with the experience after the first use, then consumers were more willing to continue to spend. The usage continuous intention refers to the intensity of personal intention of users to continue to use after the initial consumption experience, while the influence of variables such as individual factors and social environment of users would affect the repeated purchase intention of users. This study assumes that the continuous intention is the subjective willingness of learners to use an e-reading APP again after using it for the first time, and satisfaction was the overall perception and evaluation of the APP by users in the process of using an e-reading APP.

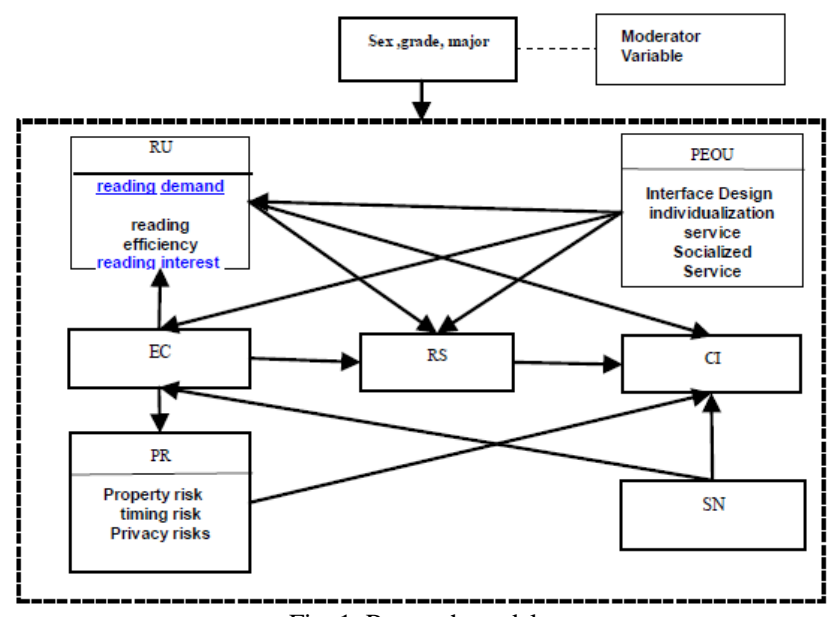

Fig. 1. Research model.

In order to propose the continuous use of information system at the bottom of the economic pyramid, Akter (2013) [28] developed a mobile health (mHealth) continuous model, constructed the perceived service quality and perceived trust, expanded the perspective of ECM (expectancy confirmation model), and studied the use of continuous information service, service quality and consumer trust. Research results confirmed that the integrated ECM, perceived service quality and perceived trust had significant explanatory power and could better predict the usage continuance intentions. Thus, in the study, $\mathrm{H} 1, \mathrm{H} 2$, and $\mathrm{H} 3$ were proposed.

$\mathrm{H} 1$ : reading usefulness of e-reading APP is positively related to users' rending satisfaction with e-reading APP.

$\mathrm{H} 2$ : reading usefulness of e-reading APP is positively related to their continuance Intentions of e-reading APP.

H3: satisfaction with e-reading apps is positively related to continuance Intentions e-reading apps

Perceived ease of use and perceived risk

Perceived ease of use refers to learners' assessment of the aesthetics, system operability, interactivity and convenience 
of e-reading APP interface. Der Heijden(2004) [29] studied the continuous usage intention of users of hedonic information system and found that perceived ease of use has a positive impact on the continuous use intention, and the influence of perceived ease of use was greater than that of perceived usefulness. Wang and Du (2014) [30] introduced mobile social networking sites (MSNS) into teaching as an innovative teaching tool, proposed a behavioral model based on the framework of "cognition-emotion-identity", and found that the perceived quality in pedagogy is an important reason affecting student satisfaction and continuous use.

The convenience, aesthetics, personalization, interactivity, security and other factors of the interface of e-reading APP have become the factors influencing undergraduates' choice of reading APP. Stone and Gronhaug (1993) [31] indicated that the consumer may be in financial, time, physical, social, psychological, and unpredictable losses on performance risk. In this study, perceived risk refers to the degree to which users perceive risks such as property, privacy and time in the process of using e-reading APP. H4, H5 and $\mathrm{H} 6$ were proposed in the research model.

H4: perceived ease of use of e-reading apps is positively related to their reading usefulness of e-reading apps.

H5: perceived ease of use of e-reading apps is positively related to their satisfaction with e-reading apps.

H6: perceived risk of e-reading apps is positively related to their rending satisfaction with e-reading apps.

Expectation confirmation and subjective norms

Bhattacherjee (2001)'s expectation confirmation refers to the difference between the initial expectation of the user before using the information system and the actual performance of the system after using the information system. If the initial expectation is greater than the actual performance, the user's satisfaction with the system and continuous innovation it will decrease. On the contrary, if the actual performance is greater than the initial expectation and users feel gratified and happy, it will improve users' satisfaction with the system and their continuous innovation. In a computer science course, Basnet et al. (2018) [27] explored students' continuance intentions of Kattis (an online automated practice and evaluation system). The results of this study showed that students' satisfaction with the system, their expectations confirmation of the system were the motivations for students to continue to use Kattis.

When individuals feel the external environment pressure brought by social network members, they decide to take a particular behavior, which is called subjective norm. According to rational behavior theory, individual behavior intention is influenced by individual behavior subjective norm. Scholars have shown in their studies on social network learning that social influencing factors are important factors affecting the sustained willingness of social network e-learning [32], [33]. Taking the famous social network in South Korea as an example, Kim (2011) [34] added subjective paradigm into the ECM-IT model to verify various factors that affected the continuous usage intention of social networking sites. On the basis of previous studies and in combination with the characteristics of undergraduates' use of e-reading APPs, this study defined the subjective criterion as when undergraduates consider using e-reading apps, they are influenced by their family members, friends, classmates and teachers who they consider important. Thus, H7, H8, H9, H10, H11, and H12 were proposed.

H7: users' expected confirmations of e-reading apps is positively related to their reading usefulness of e-reading apps.

H8: users' expected confirmations of e-reading apps is positively related to their perceived ease of use of e-reading apps.

H9: users' expected confirmations of e-reading apps is positively related to their perceived risks of e-reading apps.

H10: expectation confirmation degree of e-reading APP is positively related to users' reading satisfaction with e-reading APP.

H11: subjective norms is positively related to their expected confirmation of e-reading apps.

H12: subjective norms is positively related to their continuance Intentions e-reading apps.

\section{METHOD}

The research data collection was according to the questionnaire method. The questionnaire was consists of two parts. The first part was a survey on the participants' basic information and their e-reading habits ( 7 items). The second part, as the main part of the questionnaire, was designed in the form of 5-level Likert scale. The options of each question included 5 levels, indicating the respondents' recognition of the description of the question, so as to explore the factors that affected undergraduates' willingness to use the e-reading APP continuously. The questionnaire of 7 latent variables, reading usefulness (5 items), perceived ease of use (5 items), perceived risk ( 3 items), expectation confirmation (3 items), subjective norms ( 3 items), rending satisfaction (4 items) and continuance intentions (4 items), was a total of 34 items.

The survey was distributed in two stages. In the first stage, based on existing relevant studies, in order to test the internal consistency and content validity of the questionnaire, two classes of students in the fourth grade majoring in education technology in a Chinese university participated in the survey. SPSS 18.0 showed that the reliability and validity of the questionnaire were good. Combined with the characteristics of e-reading, the questionnaire was modified, and the two items of "I downloaded the e-reading APP because I saw its promotion" and "if I change the e-reading APP, there may be some unexpected troubles in use" were deleted.

In the second stage, the survey was distributed in a large scale, and 1261 participants were involved. Those who haven't used e-reading APPs before were seen as invalid participants. The participants who gave the same answer to the vast majority of the questionnaires and whose answer time was less than 150 seconds were seen as invalid participants either. Finally there were 629 valid answer sheets. 


\section{Data AnAlysis AND Results}

As Table I shown, male undergraduates account for $20.4 \%$ and female undergraduates account for $79.6 \% .17 .8 \%$ of the undergraduates chose to read iReader by hand in the 11 kinds of e-reading apps on display, and more than $10 \%$ chose to read on QQ, Baidu and KINDLE. In terms of majors, 55.5\% were liberal arts undergraduates, $42.9 \%$ were science undergraduates, and only $1.6 \%$ were arts and sports undergraduates. In terms of grades, it included $30.7 \%$ of freshmen, $19.3 \%$ of sophomores, $31.9 \%$ of juniors and $18.2 \%$ of seniors.

In addition, the undergraduates' daily use of e-reading APPs were also investigated and counted . According to the survey, $91.9 \%$ of the undergraduates used their fragmented time to complete the tasks of e-reading, such as waiting for a bus, in spare time or before going to bed to kill boring time. Only $2.9 \%$ of the undergraduates had fixed time to use the e-reading APP every day. 5.2\% of the undergraduates would spend plenty of time on e-reading apps every day. $27.8 \%$ of them used e-reading APPs every day. $49.0 \%$ of the undergraduates said they were not sure how often they used the e-reading APP in a week. $21.9 \%$ of the undergraduates said they would use it 3-5 times a week. $1.3 \%$ of the undergraduates occasionally use e-reading apps.

Furthermore , most undergraduates $(58.3 \%)$ had the habit of using an e-reading APP for 1-2 years, $14.6 \%$ had been using an e-reading APP for 6-6 months, 9.5\% had been using an e-reading APP for 3-6 months, and $17.6 \%$ had just started using an e-reading APP (less than 3 months). It could be seen that the vast majority of the undergraduates used the e-reading APPs in their fragmented time, but only about a quarter of them would stick to a certain e-reading APP every day, and nearly half of the undergraduates were not sure about the frequency of their use in a week.

TABLE I: USAGE STATISTICS OF E-READING APPS

\begin{tabular}{|c|c|c|c|c|c|}
\hline & & frequency & $\begin{array}{l}\text { V. PERCE } \\
\text { NTAGE }\end{array}$ & $\begin{array}{l}\text { Effective } \\
\text { percentage }\end{array}$ & $\begin{array}{l}\text { cumulative } \\
\text { percentage }\end{array}$ \\
\hline \multirow{3}{*}{ gender } & male & 126 & 20.4 & 20.4 & 20.4 \\
\hline & VI. FEMALE & 492 & 79.6 & 79.6 & 100.0 \\
\hline & total & 618 & 100.0 & 100.0 & \\
\hline \multirow{4}{*}{ subject } & Liberal Arts & 343 & 55.5 & 55.5 & 55.5 \\
\hline & $\begin{array}{l}\text { Science and } \\
\text { engineering }\end{array}$ & 265 & 42.9 & 42.9 & 98.4 \\
\hline & art and PE & 10 & 1.6 & 1.6 & 100.0 \\
\hline & total & 618 & 100.0 & 100.0 & \\
\hline \multirow{5}{*}{ grade } & freshman & 239 & 38.7 & 38.7 & 38.7 \\
\hline & sophomore & 119 & 19.3 & 19.3 & 57.9 \\
\hline & junior & 197 & 31.9 & 31.9 & 89.8 \\
\hline & VII. SENIOR & 63 & 10.2 & 10.2 & 100.0 \\
\hline & total & 618 & 100.0 & 100.0 & \\
\hline $\begin{array}{l}\text { E-reading } \\
\text { APP }\end{array}$ & $\begin{array}{l}\text { WeChat } \\
\text { reading }\end{array}$ & 46 & 7.4 & 7.4 & 7.4 \\
\hline
\end{tabular}

\begin{tabular}{|c|c|c|c|c|c|c|c|}
\hline & \multicolumn{2}{|c|}{ KINDLE } & \multicolumn{2}{|l|}{64} & 10.4 & 10.4 & 17.8 \\
\hline & \multicolumn{2}{|c|}{$\begin{array}{l}\text { Palm reading } \\
\text { iReader }\end{array}$} & \multicolumn{2}{|c|}{110} & 17.8 & 17.8 & 35.6 \\
\hline & \multicolumn{2}{|c|}{$\begin{array}{l}\text { Netease snail } \\
\text { reading }\end{array}$} & \multicolumn{2}{|l|}{18} & 2.9 & 2.9 & 38.5 \\
\hline & \multicolumn{2}{|c|}{ iBooks } & \multicolumn{2}{|l|}{8} & 1.3 & 1.3 & 39.8 \\
\hline & \multicolumn{2}{|c|}{ Pandareader } & \multicolumn{2}{|l|}{2} & .3 & .3 & 40.1 \\
\hline & \multicolumn{2}{|c|}{ read-douban } & \multicolumn{2}{|l|}{21} & 3.4 & 3.4 & 43.5 \\
\hline & \multicolumn{2}{|c|}{ QQ reading } & \multicolumn{2}{|l|}{69} & 11.2 & 11.2 & 54.7 \\
\hline & \multicolumn{4}{|c|}{ Baidu reading 91} & 14.7 & 14.7 & 69.4 \\
\hline & \multicolumn{2}{|c|}{ EasyReader } & \multicolumn{2}{|l|}{16} & 2.6 & 2.6 & 72.0 \\
\hline & \multicolumn{2}{|c|}{$\underline{\text { Migu Readin }}$} & 5 & & .8 & .8 & 72.8 \\
\hline & \multicolumn{2}{|c|}{$\underline{\text { all dislike }}$} & \multicolumn{2}{|l|}{56} & 9.1 & 9.1 & 81.9 \\
\hline & \multicolumn{2}{|c|}{ others } & 112 & 18.1 & & 18.1 & 100.0 \\
\hline & total & & 618 & 100. & & 100.0 & \\
\hline & & TABLE & II: 1 & FACTOR ANA & LYSIS ( & $N=629)$ & \\
\hline Constructs & Item & $\begin{array}{l}\text { Item } \\
\text { reliabil }\end{array}$ & & $\begin{array}{l}\text { Composite } \\
\text { reliability }\end{array}$ & $\begin{array}{l}\text { Averag } \\
\text { extract }\end{array}$ & $\begin{array}{l}\text { e variance } \\
\text { ed (AVE) }\end{array}$ & Cronbach $\alpha$ \\
\hline $\begin{array}{l}\text { Reading } \\
\text { Usefulness } \\
(\mathrm{RU})\end{array}$ & $\begin{array}{l}\text { RU1 } \\
\text { RU2 } \\
\text { RU3 } \\
\text { RU4 } \\
\text { RU5 } \\
\text { RU6 }\end{array}$ & $\begin{array}{l}.65 \\
.72 \\
.79 \\
.80 \\
.82 \\
.80\end{array}$ & & .894 & .586 & & .893 \\
\hline $\begin{array}{l}\text { Expectation } \\
\text { Confirmatio } \\
\mathrm{n} \\
(\mathrm{EC})\end{array}$ & $\begin{array}{l}\mathrm{EC} 1 \\
\mathrm{EC} 2 \\
\mathrm{EC} 3\end{array}$ & $\begin{array}{l}.86 \\
.88 \\
.87\end{array}$ & & 0.903 & 0.757 & & 0.903 \\
\hline $\begin{array}{l}\text { Perceived } \\
\text { Ease of Use } \\
(\mathrm{PEOU})\end{array}$ & $\begin{array}{l}\text { PEO } \\
\text { U1 } \\
\text { PEO } \\
\text { U2 } \\
\text { PEO } \\
\text { U3 } \\
\text { PEO } \\
\text { U4 }\end{array}$ & $\begin{array}{l}.59 \\
.72 \\
.83 \\
.80\end{array}$ & & 0.827 & 0.549 & & 0.836 \\
\hline $\begin{array}{l}\text { Perceived } \\
\text { Risk } \\
(\mathrm{PR})\end{array}$ & $\begin{array}{l}\text { PR1 } \\
\text { PR2 } \\
\text { PR3 }\end{array}$ & $\begin{array}{l}.78 \\
.84 \\
.89\end{array}$ & & 0.876 & 0.702 & & 0.874 \\
\hline $\begin{array}{l}\text { subjective } \\
\text { Norm } \\
(\mathrm{SN})\end{array}$ & $\begin{array}{l}\mathrm{SN} 1 \\
\mathrm{SN} 2 \\
\mathrm{SN} 3\end{array}$ & $\begin{array}{l}.78 \\
.83 \\
.68 \\
\end{array}$ & & 0.809 & 0.587 & & 0.803 \\
\hline $\begin{array}{l}\text { Reading } \\
\text { Satisfaction } \\
\text { (RS) }\end{array}$ & $\begin{array}{l}\text { US1 } \\
\text { US2 } \\
\text { US3 } \\
\text { US4 }\end{array}$ & $\begin{array}{l}.90 \\
.90 \\
.82 \\
.70\end{array}$ & & 0.901 & 0.696 & & 0.899 \\
\hline $\begin{array}{l}\text { continuance } \\
\text { Intentions } \\
\text { (CI) }\end{array}$ & $\begin{array}{l}\text { CI1 } \\
\text { CI2 }\end{array}$ & $\begin{array}{l}.90 \\
.85\end{array}$ & & 0.918 & 0.692 & & 0.921 \\
\hline $\begin{array}{l}\text { continuance } \\
\text { Intentions } \\
\text { (CI) }\end{array}$ & $\begin{array}{l}\mathrm{CI} 4 \\
\mathrm{CI} 3\end{array}$ & $\begin{array}{l}.79 \\
.82\end{array}$ & & 0.906 & 0.707 & & 0.921 \\
\hline
\end{tabular}

\section{A. Reliability and Validity of the Instrument}

In order to ensure the validity of the measurement model, 
Amos 24.0 was used to conduct confirmatory factor analysis on the measurement scale. In general, Cronbach's Alpha value and $\mathrm{CR}$ value of potential variables reach 0.6 [35], which proves that the measurement model has good reliability. In this study, CR values were greater than or equal to 0.809 , Cronbach's Alpha values were greater than or equal to 0.803 , indicated that the measurement scale had good reliability.

In this study, scale validity was measured by AVE, including convergent validity and discriminant validity. It is generally believed that when the AVE of all factors of the model is greater than 0.5 , the convergence validity of potential variables is better [36]. When the AVE square root of potential variables is larger than the correlation coefficient between other related variables, the model has better discriminant validity. The AVE values in this study were all greater than 0.549 (see Table II), indicating that the measurement model had ideal convergent validity. The AVE square root of the potential variable was all greater than the correlation coefficient between the potential variable and other potential variables, indicating that the measurement model had good discriminative validity [37] (see Table III).

\begin{tabular}{|c|c|c|c|c|c|c|c|}
\hline & RU & PEOU & SN & $\mathrm{EC}$ & PR & $\mathrm{RS}$ & CI \\
\hline RU & 0.766 & & & & & & \\
\hline PEOU & 0.617 & 0.741 & & & & & \\
\hline $\mathrm{SN}$ & 0.699 & 0.138 & 0.766 & & & & \\
\hline $\mathrm{EC}$ & 0.473 & 0.610 & 0.679 & 0.870 & & & \\
\hline PR & 0.088 & 0.206 & 0.071 & 0.827 & 0.838 & & \\
\hline RS & 0.229 & 0.112 & 0.049 & 0.549 & 0.059 & 0.834 & \\
\hline $\mathrm{CI}$ & 0.232 & 0.070 & 0.032 & 0.060 & 0.001 & 0.776 & 0.841 \\
\hline
\end{tabular}

\section{B. Hypotheses Testing}

The study adopted the confirmatory factor analysis method to examine the structural model. The goodness-of-fit index (GFI), and adjusted goodness-of-fit index (AGFI) should be more than the suggested value of 0.9 and less than 1.0 [38]. The value of GFI and AGFI was 0.887 and 0.864 . The normed fit index (NFI) and comparative fit index (CFI) should all be greater than 0.9 [39]. The value of NFI and CFI was 0.924 and 0.948 . The root mean square error of approximate (RMSEA) should be less than 0.1 [40], and the value of this study model is 0.057 . The chi-square degree of freedom was 3.627 which was under the acceptable threshold level of 5.0 [41]. The remaining index parameters were consistent with the study. It could be seen that the study model had a good model fit.

The hypothesis test results of the research model were as follows (see Table IV). The expected confirmation was significantly affected by subjective norms $(\beta=0.73, p<0.01)$, and significantly affected perceived ease of use $(\beta=0.69$, $\mathrm{p}<0.01)$, perceived risk $(\beta=0.68, p<0.01)$, reading usefulness $(\beta=0.38, p<0.01)$ and satisfaction $(\beta=0.60, p<0.01)$. Reading usefulness was significantly affected by perceived ease of use $(\beta=0.56, \quad p<0.01)$, satisfaction $(\beta=0.24, \quad p<0.001)$ and continuance Intentions $\quad(\beta=0.17, \quad p<0.01)$. Satisfaction significantly affected learners' continuance Intentions $(\beta=0.73, \quad p<0.001)$. However, satisfaction was not significantly affected by perceived risk $(\beta=0.05, p=0.138)$ and perceived ease of use $(\beta=0.09, p=0.079)$. Subjective specifications $(\beta=-0.02, p=0.661)$ did not significantly affect the continuance intentions. Hypothesis 5, 6, and 12 are untested.

TABLE IV: INTER-CORRELATION AMONG CONSTRUCTS

\begin{tabular}{lllll}
\hline Hypothesis & Causal Factors & $\begin{array}{l}\text { Path } \\
\text { Coefficient }\end{array}$ & $P$ & Result \\
\hline H1 & RU $\rightarrow$ US & 0.24 & $P<0.001$ & support \\
\hline H2 & RU $\rightarrow$ CI & 0.17 & $P<0.001$ & support \\
\hline H3 & US $\rightarrow$ CI & 0.73 & $P<0.001$ & support \\
\hline H4 & PEOU $\rightarrow$ RU & 0.56 & $P<0.001$ & support \\
\hline H5 & PEOU $\rightarrow$ US & 0.09 & $P=0.079$ & unsupport \\
\hline H6 & PR $\rightarrow$ US & 0.05 & $P=0.138$ & unsupport \\
\hline H7 & EC $\rightarrow$ RU & 0.38 & $P<0.001$ & support \\
\hline H8 & EC $\rightarrow$ PEOU & 0.69 & $P<0.001$ & support \\
\hline H9 & EC $\rightarrow$ PR & 0.68 & $P<0.001$ & support \\
\hline H10 & EC $\rightarrow$ US & 0.60 & $P<0.001$ & support \\
\hline H11 & SN $\rightarrow$ EC & 0.73 & $P<0.001$ & support \\
\hline H12 & SN $\rightarrow$ CI & 0.02 & $P=0.661$ & unsupport \\
\hline
\end{tabular}

\section{Model Modification}

In order to improve the fitting degree of the model, the following adjustments were made. First, the relationship of common variables between perceived ease of use, subjective specification and continuous intention, and expected confirmation and continuous intention was established. Secondly, the influences of subjective norms on willingness to continue, perceived ease of use on satisfaction and perceived ease of use on satisfaction are removed. Finally, compared with the initial model, the degree of fitting was greatly improved. Chi-square degrees of freedom (2.193), GFI(0.923), AGFI(0.904), $\operatorname{NFI(0.946),~CFI(0.970)~and~}$ $\operatorname{RMSEA}(0.044)$ all met the recommended requirements(see Fig. 2).

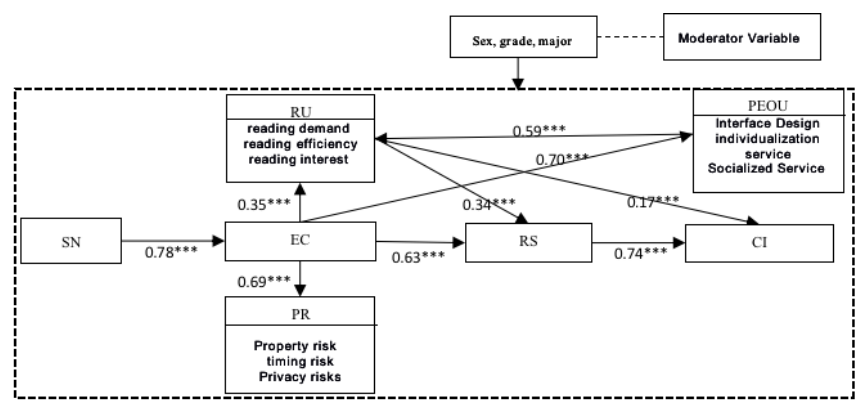

Fig. 2. Model testing results.

Note : *** $P<0.001$

\section{DISCUSSION AND CONCLUSION}

Based on the expected confirmation model and D\&M information system success model, subjective norm and 
perceived risk were introduced to establish the model. The results of data analysis were as same as the results shown in ECM-IT [16] that the expectation confirmation significantly affected reading usefulness and user satisfaction, reading usefulness was significantly affected satisfaction and continuous intentions. And expectation confirmation significantly affected perceived risk [42] and perceived ease of use which confirmed the results of previous studies.

The data suggested that perceived ease of use did not affect continuous intentions, but did affect reading usefulness, which was an extra finding of the study different from the existing study [29], [30]. Therefore, it could be seen that factors influencing the continuous intentions to use e-reading APPs were related to reading usefulness, perceived ease of use, perceived risk, subjective norms and satisfaction. However, this study found that satisfaction was not significantly affected by perceived risk and perceived ease of use.

Unlike previous studies [32]-[34] subjective norms did not significantly affect continuous intentions, but significantly affected expectation confirmation. Besides, From the overall effect of the model, the largest influencing factors for undergraduates' continuous use of electronic APP were confirmed expectation and satisfaction, while subjective norms, reading usefulness and perceived ease of use had an influence on continuance intentions successively (see Table $\mathrm{V})$. In view of all the above results, analysis and suggestions were given as follows.

TABLE V: THE ARRANGEMENT OF CHANNELS

\begin{tabular}{lccccccc}
\hline \hline & SN & EC & PEOU & RU & US & CI & PR \\
\hline EC & .776 & .000 & .000 & .000 & .000 & .000 & .000 \\
\hline PEOU & .544 & .701 & .000 & .000 & .000 & .000 & .000 \\
\hline RU & .593 & .764 & .587 & .000 & .000 & .000 & .000 \\
\hline US & .685 & .882 & .198 & .337 & .000 & .000 & .000 \\
\hline CI & .604 & .777 & .244 & .416 & .736 & .000 & .000 \\
\hline \hline PR & .533 & .686 & .000 & .000 & .000 & .000 & .000 \\
\hline \hline
\end{tabular}

\section{A. Increase Advertising and Focus on the Quality of e-Reading APPs Content}

Subjective norms did not have a direct impact on the willingness to continuance using, but could significantly affect the degree of users' expected confirmation of e-reading apps. Undergraduates' choice of e-reading APP would be affected by the interpersonal relationship and social environment around them, but they would not blindly follow. Their willingness or behavior to continue using e-reading APPs was due to their own requirements for e-reading APPs. The fast-paced life style also changed the way undergraduates read. However, high quality and interesting e-reading content may be the key parts of their requirements.

\section{B. Enhance System Stability and Awareness of Prevention}

The perceived risk was significantly affected by the degree of expected confirmation. It showed that under the current atmosphere of online learning and social learning, undergraduates paid more attention to the protection of privacy when they come into contact with various paid reading software. However, perceived risk had no significant influence on user satisfaction, which could be explained as follows: first, undergraduates had great confidence in the safety of the current e-reading APPs, and they needed to worry about their personal information leakage and property loss; Second, undergraduates were aware of the importance of personal information such as their privacy, but did not put it into action; Third, the security of certain e-reading APP was excluded from the standards of evaluating the e-reading APPs for undergraduates. To sum up, the design and development of an e-reading APP should not only ensure the stability of the APP system, but also set relevant information to remind users of matters needing attention in use, so as to avoid the loss of time and property.

\section{Beautify Operating Interface with Intelligent and Convenient Interactive Services}

Although the market competition inevitably brings some criticism, the competition promotes the quality of the e-reading APPs. For example, in order to win a larger consumer market, the designer and developer strive to make the interface design and operation of e-reading APPs simple, beautiful, and convenient. Although the popularity of electronic devices, especially mobile phones and other mobile devices, makes undergraduates have better media literacy, it can be seen from the results of the study that undergraduates have great expectations for the interface design, interaction demand and ease of use of e-reading APPs. Perceived ease of use had a significant effect on reading usefulness. The operability, personalized service and social service of e-reading APP had virtually promoted learners' understanding of reading content. Thus, diversified visualization methods such as graphic presentation and video will be more favored by learners in content design, and it is particularly important to provide intelligent and convenient personalized and social services in interaction. However, in this study, it was found that learners' perceived ease of use of e-reading APPs did not significantly affect undergraduates' satisfaction with e-reading APPs.

In addition, the promotion of e-reading apps couldn't be ignored. Although subjective norms couldn't make learners keep using e-reading apps, they were an important way to attract undergraduates to accept an e-reading APP and start using it.

\section{Limitation and Future Study}

The research applied a questionnaire to test the influencing factors of undergraduates' continuance intentions in E-reading APPs. 12 hypotheses were proposed and confirmatory factor analysis was adopted to examine the structural model. Model modification was also used to improve the fitting degree of the model. The result showed H5, H6 and H12 were not supported. Suggestions of encouraging undergraduates to continue using E-reading APPs were given. It is necessary to increase advertising and focus on the reading contents, enhance system stability and awareness of prevention, and beautify operating interface with intelligent and convenient interactive services. Further 
research and analysis are required to determine whether e-reading APPs can only be used for fragmented reading content, or whether fragmentation affects learners' willingness to continue using an e-reading APP.

\section{APPENDIX}

\begin{tabular}{|c|c|c|}
\hline Construct & Explanation and Items & source \\
\hline \multirow{7}{*}{$\begin{array}{l}\text { Reading } \\
\text { Usefulness } \\
\text { (RU) }\end{array}$} & $\begin{array}{l}\text { The evaluation on the degree to which e-reading } \\
\text { APP can meet reading needs, improve reading } \\
\text { efficiency and interest. }\end{array}$ & \multirow{3}{*}{$\begin{array}{l}\text { Oliver } \\
(1980) \\
{[15]} \\
\text { Davis et al } \\
(1989) \\
{[26]}\end{array}$} \\
\hline & $\begin{array}{l}\text { RU1:The e-reading APP can provide the books I } \\
\text { need. }\end{array}$ & \\
\hline & $\begin{array}{l}\text { RU2:E-reading APP can effectively improve my } \\
\text { reading efficiency. }\end{array}$ & \\
\hline & $\begin{array}{l}\text { RU3:The e-reading APP has changed my way of } \\
\text { reading and improved my interest in reading. }\end{array}$ & \multirow{4}{*}{$\begin{array}{l}\text { Bhattahoo } \\
\text { chee } \\
(2001) \\
{[16]} \\
\text { Venkatesh } \\
\text { et al. } \\
(2003) \\
{[43]}\end{array}$} \\
\hline & $\begin{array}{l}\text { RU4:E-reading APP is a relaxing and enjoyable } \\
\text { process, which can add fun to my study. }\end{array}$ & \\
\hline & $\begin{array}{l}\text { RU5:E-reading APP has many functions, which } \\
\text { I think are very useful. }\end{array}$ & \\
\hline & $\begin{array}{l}\text { RU6:On the whole, I think e-reading APP is } \\
\text { useful. }\end{array}$ & \\
\hline \multirow{9}{*}{$\begin{array}{l}\text { perceived } \\
\text { Ease of Use } \\
\text { (PEOU) }\end{array}$} & $\begin{array}{l}\text { The evaluation on the degree of aesthetics, } \\
\text { system operability, interactivity and } \\
\text { convenience of e-reading APP. }\end{array}$ & $\begin{array}{l}\text { Dunne et } \\
\text { al }(2010) \\
{[44]}\end{array}$ \\
\hline & $\begin{array}{l}\text { PU1:E-reading apps often recommend books I } \\
\text { like. }\end{array}$ & Lee \& Ma \\
\hline & PU2:I can interact with others, communicate & [45] \\
\hline & and share my experience through e-reading APP. & \multirow{3}{*}{$\begin{array}{l}\text { Stone \& } \\
\text { Winter } \\
(1987) \\
{[46]}\end{array}$} \\
\hline & $\begin{array}{l}\text { PU3:E-reading APP books are presented in } \\
\text { various ways (graphic, audio, etc.). }\end{array}$ & \\
\hline & PU4:E-reading APP has a clear interface and is & \\
\hline & & $\begin{array}{l}(2004) \\
{[47]}\end{array}$ \\
\hline & & Pi \& \\
\hline & & $\begin{array}{l}\text { Sangruang } \\
(2011) \\
{[24]}\end{array}$ \\
\hline
\end{tabular}

\begin{tabular}{|c|c|c|}
\hline \multirow{5}{*}{$\begin{array}{l}\text { Perceived } \\
\text { Risk } \\
(\mathrm{PR})\end{array}$} & $\begin{array}{l}\text { The evaluation of the perceived risks of } \\
\text { property, privacy and time in the process of } \\
\text { using the e-reading APP }\end{array}$ & $\begin{array}{l}\text { Stone \& } \\
\text { Winter } \\
(1987)\end{array}$ \\
\hline & PR1:I don't think the e-reading APP will give & {$[46]$} \\
\hline & away my personal information. & Hans \\
\hline & $\begin{array}{l}\text { PR2:I don't think e-reading apps will take me } \\
\text { much time. }\end{array}$ & $\begin{array}{l}(2004) \\
{[47]}\end{array}$ \\
\hline & $\begin{array}{l}\text { PR3:I don't think the e-reading APP will cause } \\
\text { me unnecessary property loss. }\end{array}$ & $\begin{array}{l}\text { Pi \& } \\
\text { Sangruang } \\
(2011) \\
{[24]}\end{array}$ \\
\hline \multirow{4}{*}{$\begin{array}{l}\text { Expectation } \\
\text { Confirmatio } \\
\mathrm{n} \\
(\mathrm{EC})\end{array}$} & $\begin{array}{l}\text { The comparison between the actual performance } \\
\text { of users after using the e-reading APP and the } \\
\text { expected results in the early stage. }\end{array}$ & $\begin{array}{l}\text { Oliver } \\
(1980) \\
{[15]}\end{array}$ \\
\hline & $\begin{array}{l}\text { EC1:The benefits of using e-reading APP } \\
\text { exceeded my expectations. }\end{array}$ & $\begin{array}{l}\text { Yi (1990) } \\
{[48]}\end{array}$ \\
\hline & $\begin{array}{l}\text { EC2:Using the e-reading APP makes it easier for } \\
\text { me to integrate into the reading study, which is } \\
\text { better than I expected. }\end{array}$ & \multirow{2}{*}{$\begin{array}{l}\text { Bhattahoo } \\
\text { chee } \\
(2001) \\
{[16]}\end{array}$} \\
\hline & $\begin{array}{l}\text { EC3:In general, using the e-reading APP can } \\
\text { achieve my expected use desire. }\end{array}$ & \\
\hline $\begin{array}{l}\text { subjective } \\
\text { Norm }\end{array}$ & $\begin{array}{l}\text { The degree to which users are affected by the } \\
\text { social environment and the surrounding groups } \\
\text { when using the e-reading APP }\end{array}$ & $\begin{array}{l}\text { Venkatesh } \\
\text { et al }\end{array}$ \\
\hline
\end{tabular}

\begin{tabular}{|c|c|c|}
\hline \multirow[t]{3}{*}{$(\mathrm{SN})$} & $\begin{array}{l}\text { SN1:People around me think I should use an } \\
\text { e-reading APP }\end{array}$ & $\begin{array}{l}(2000) \\
{[49]}\end{array}$ \\
\hline & $\begin{array}{l}\text { SN2:People around me are using this e-reading } \\
\text { APP that I just use. }\end{array}$ & \multirow{2}{*}{$\begin{array}{l}\text { Venkatesh } \\
\text { et al } \\
\text { ( } 2003) \\
{[43]}\end{array}$} \\
\hline & $\begin{array}{l}\text { SN3:My classmate recommended me to use the } \\
\text { e-reading APP. }\end{array}$ & \\
\hline \multirow{5}{*}{$\begin{array}{l}\text { Reading } \\
\text { Satisfaction } \\
\text { (RS) }\end{array}$} & $\begin{array}{l}\text { The overall perception and evaluation of the } \\
\text { APP in the process of using the e-reading APP }\end{array}$ & \multirow{5}{*}{$\begin{array}{l}\text { Oliver } \\
(1980) \\
{[15]} \\
\text { Bhattahoo } \\
\text { chee } \\
(2001) \\
{[16]}\end{array}$} \\
\hline & \multirow{2}{*}{$\begin{array}{l}\text { US1:I am satisfied with the functional modules } \\
\text { provided by the e-reading APP. } \\
\text { US2:Using the e-reading APP is a wise choice } \\
\text { for me. }\end{array}$} & \\
\hline & & \\
\hline & $\begin{array}{l}\text { US3:Using the e-reading APP makes me feel } \\
\text { satisfied. }\end{array}$ & \\
\hline & $\begin{array}{l}\text { US4:I will recommend this e-reading APP to } \\
\text { people around me. }\end{array}$ & \\
\hline \multirow[b]{3}{*}{ continuance } & $\begin{array}{l}\text { The user's willingness to use the e-reading APP } \\
\text { again after using it. }\end{array}$ & \multirow{2}{*}{$\begin{array}{l}\text { Oliver } \\
(1980) \\
{[15]}\end{array}$} \\
\hline & $\begin{array}{l}\text { CI1:It is a natural behavior for me to read on the } \\
\text { e-reader APP. }\end{array}$ & \\
\hline & $\begin{array}{l}\text { CI2:I will use the e-reading APP in my daily life } \\
\text { and study in the future. }\end{array}$ & $\begin{array}{l}\text { chee } \\
(2001)\end{array}$ \\
\hline \multirow[t]{2}{*}{$\begin{array}{l}\text { Intentions } \\
\text { (CI) }\end{array}$} & $\begin{array}{l}\text { CI3:I will read more types of books on the } \\
\text { e-reading APP in the future. }\end{array}$ & \multirow{2}{*}{$\begin{array}{l}\text { Mathieson } \\
(1991) \\
{[50]}\end{array}$} \\
\hline & $\begin{array}{l}\text { CI4:It has become my habit to reading on the } \\
\text { e-reading APP. }\end{array}$ & \\
\hline
\end{tabular}

\section{CONFLICT OF INTEREST}

The authors declare no conflict of interest.

\section{AUTHOR CONTRIBUTIONS}

Li Zhao conducted the research; Wenqian Lai analyzed the data; Wenqian Lai wrote the original draft; Li Zhao reviewed and edited the final paper; all authors had approved the final version.

\section{ACKNOWLEDGMENT}

This research was supported in part by a grant from the Collaborative Innovation Center for Talent Cultivating Mode in Basic Education; and the Priority Academic Program Development of Jiangsu Higher Education Institutions in China.

\section{REFERENCES}

[1] M. Martins, J. S. Farias, P. H. Melo Albuquerque, and D. S. Pereira, "Adoption of technology for reading purposes: A study of e-books acceptance," Brazilian Business Review (English Edition), vol. 15, pp. $568-588,2018$.

[2] E. Safley, "Demand for e-books in an academic library," Journal of Library Administration, vol. 45, pp. 445-457, 2006.

[3] W. H. DeLone and E. R. McLean, "Information systems success: The quest for the dependent variable," Information Systems Research, vol. 3, pp. 60-95, 1992.

[4] W. H. DeLone and E. R. McLean, "The DeLone and McLean model of information systems success: A ten-year update," Journal of Management Information Systems, vol. 19, pp. 9-30, 2003.

[5] K. M. Alraimi, H. Zo, and A. P. Ciganek, "Understanding the MOOCs continuance: The role of openness and reputation," Computers \& Education, vol. 80, pp. 28-38, 2015. 
[6] Y. M. Huang, "Examining students' continued use of desktop services: Perspectives from expectation-confirmation and social influence,' Computers in Human Behavior, vol. 96, pp. 23-31, 2019.

[7] Y.M. Huang, "Exploring students' acceptance of team messaging services: The roles of social presence and motivation," British Journal of Educational Technology, vol. 48, pp. 1047-1061, 2017.

[8] C. H. Liu and Y. M. Huang, "An empirical investigation of computer simulation technology acceptance to explore the factors that affect user intention," Universal Access in the Information Society, vol. 14, pp. 449-457, 2015.

[9] J. O. Borchers, "Electronic books: definition, genres, interaction design patterns," Workshop on Electronic Books, CHI'99 International Conference on Human Factors in Computing Systems, Pittsburgh, PA, 1999.

[10] E. Siegenthaler, L. Phil, P. Wurtz, and R. Groner, "Improving the usability of e-book readers," Journal of Usability Studies, vol. 6, pp. $25-38,2010$.

[11] C. C. Lin, W. C. Chiou, and C. C. Huang, "The challenges facing e-book publishing industry in Taiwan," Procedia Computer Science, vol. 17, pp. 282-289, 2013

[12] K. Dustin and G. Blake, "VR practical applications - develop the world's most popular VR e-reader," Media in China, vol. 22, pp. 25-27, 2018.

[13] A. A. Hadaya and M. Hanif, "The impact of using the interactive e-Book on students' learning outcomes," International Journal of Instruction, vol. 12, pp. 709-722, 2019.

[14] C. Sanford, "An artifact switching model for user acceptance of e-books," Journal of Organization and End User Computing, vol.25, pp. 19-40, 2013.

[15] R. L. Oliver, "A cognitive model of the antecedents and consequences of satisfaction decisions," Journal of Marketing Research, vol. 17, pp 460-469, 1980

[16] A. Bhattacherjee, "Understanding information systems continuance: An expectation-confirmation model," MIS Quarterly, vol. 25, pp. 351-370, 2001.

[17] J. Y. L. Thong, S. J. Hong, and K. Y. Tam, "The effects of post-adoption beliefs on the expectation-confirmation model for information technology continuance," Social Science Electronic Publishing, vol. 64, pp. 799-810, 2006

[18] J. Zhou, "Exploring the factors affecting learners' continuance intention of moocs for online collaborative learning: an extended ecm perspective,' Australasian Journal of Educational Technology, vol. 33, pp. 123-135, 2017.

[19] C. Tam, D. M. Santos, and T. Oliveira, "Exploring the influential factors of continuance intention to use mobile Apps: Extending the expectation confirmation model," Information Systems Frontiers, pp. 1-15, 2018.

[20] I. Balaban, E. Mu, and B. Divjak, "Development of an electronic portfolio system success model: An information systems approach," Computers \& Education, vol. 60, pp. 396-411, 2013.

[21] H. Mohammadi, "Investigating users' perspectives on e-learning: an integration of tam and is success model," Computers in Human Behavior vol. 45 , pp. 359-374, 2015

[22] A. H. Aldholay, O. Isaac, Z. Abdullah, et al., "The role of transformational leadership as a mediating variable in DeLone and McLean information system success model: The context of online learning usage in Yemen," Telematics and Informatics, vol. 35, pp 1421-1437, 2018.

[23] R. Orji, "Impact of gender and nationality on acceptance of a digital library: an empirical validation of nationality based utaut using sem," Journal of Emerging Trends in Computing \& Information Sciences, vol. 1, pp. 68-79, 2010.

[24] S. Pi and J. Sangruang, "The perceived risks of online shopping in Taiwan," Social Behavior and Personality: An International Journal, vol. 39, pp. 275-286, 2011

[25] M. Pinto, C. Pouliot, and J. A. Cordón-García, "E-book reading among Spanish university students," Electronic Library, vol. 32, pp. 473-492, 2014.

[26] F. D. Davis, R. P. Bagozzi, and P. R. Warshaw, "User acceptance of computer technology: a comparison of two theoretical models," Management Science, vol. 35, pp. 982-1003, 1989.

[27] R. B. Basnet, T. Doleck, D. J. Lemay, and P. Bazelais, "Exploring computer science students' continuance intentions to use kattis," Education and Information Technologies, vol. 23, pp. 1145-1158, 2018.

[28] S. Akter, P. Ray, and J. D'Ambra, "Continuance of mhealth services at the bottom of the pyramid: The roles of service quality and trust,' Electronic Markets, vol. 23, pp. 29-47, 2013.

[29] H. V. Heijden, "User acceptance of hedonic information systems," Management Information Systems Quarterly, vol. 28, pp. 695-704, 2004.
[30] R. B. Wang and C. T. Du, "Mobile social network sites as innovative pedagogical tools: Factors and mechanism affecting students' continuance intention on use," Journal of Computers in Education, vol. 1, pp. 353-370, 2014.

[31] R. N. Stone, and K. Gronhaug, "Perceived risk: Further considerations for the marketing discipline," European Journal of Marketing, vol. 27, pp. 39-50, 1993.

[32] I. Adaji and J. Vassileva, "Perceived effectiveness, credibility and continuance intention in e-commerce: A study of Amazon," Persuasive Technology: Development and Implementation of Personalized Technologies to Change Attitudes and Behaviors, pp. 293-306, 2017.

[33] I. Lai and D. Lai, "Understanding students' continuance intention toward social networking e-learning," Hybrid Learning. Theory and Practice, pp. 173-183, 2014

[34] B. Kim, "Understanding antecedents of continuance intention in social-networking services," Cyberpsychology, Behavior, and Social Networking, vol. 14, pp. 199-205, 2011.

[35] R. P. Bagozzi and Y. Youjae, "On the evaluation of structural equation models," Journal of the Academy of Marketing Science, vol. 16, pp. 74-94, 1988.

[36] C. Fornell and D. F. Larcker, "Evaluating structural equation models with unobservable variables and measurement error," Journal of Marketing Research, vol. 18, pp. 39-50, 1981.

[37] W. Chin, "Commentary: Issues and opinion on structural equation modeling," MIS Quarterly, vol. 22, pp. Vii-Xvi, 1998

[38] J. J. Foster, E. Barkus, and C. Yavorsky, Understanding and Using Advanced Statistics: A Practical Guide for Students, London: SAGE, 2006.

[39] J. F. Hair, B. Black, B. Babin, R. E. Anderson, and R. L. Tatham, Multivariate Data Analysis, New Jersey: Prentice Hall, 2006.

[40] J. C. Anderson and D. W. Gerbing, "Structural equation modeling in practice: A review and recommended two-step approach," Psychological Bulletin, vol. 103, pp. 411-423, 1988.

[41] P. M. Bentler and D.C. Bonnet, "Significance tests and goodness of fit in the analysis of covariance structures," Psychological Bulletin, vol. 88, pp. 588-606, 1980.

[42] S. M. Forsythe and B.Shi, "Consumer patronage and risk perceptions in internet shopping," Journal of Business Research, vol. 56, pp. 867-875, 2003.

[43] V. Venkatesh, M. G.Morris, G. B. Davis, and F. D. Davis, "User acceptance of information technology: Toward a unified view," MIS Quarterly, vol. 27, pp. 425-478, 2003.

[44] A. Dunne, M. Lawlor, and J. Rowley, "Young people's use of online social networking sites-a uses and gratifications perspective," Journal of Research in Interactive Marketing, vol. 4, pp. 46-58, 2010.

[45] C. S. Lee and L. Ma, "News sharing in social media: The effect of gratifications and prior experience," Computers in Human Behavior, vol. 28, pp. 331-339, 2012.

[46] R. N. Stone and F. W. Winter, "Risk: Is it still uncertainty times consequences?" AMA Winter Educators' Conference Proceedings, $\mathrm{p}$ $261,1987$.

[47] V. D. H. Hans, "User acceptance of hedonic information systems," MIS Quarterly, vol. 28, pp. 695-704, 2004.

[48] Y. Yi, "A critical review of consumer satisfaction," Review of Marketing, vol. 4, pp. 68-123, 1990.

[49] V. Venkatesh and F. D. Davis, "A theoretical extension of the technology acceptance model: four longitudinal field studies," Management Science, vol. 45 , pp. 186-204, 2000.

[50] K. Mathieson, "Predicting user intentions: comparing the technology acceptance model with the theory of planned behavior," Information Systems Research, vol. 2, pp. 173-191, 1991.

Copyright (C) 2019 by the authors. This is an open access article distributed under the Creative Commons Attribution License which permits unrestricted use, distribution, and reproduction in any medium, provided the original work is properly cited (CC BY 4.0).

Wenqian Lai was born in Hangzhou, China, on Nov. 16, 1994. She is graduate student, educational technology, School of Education Science, Nanjing Normal University. Nanjing, China. She was an undergraduate student at Northwest Minzu University from 2014 to 2017 and earned her bachelor degree in 2017.

Li Zhao was born in Nanjing, China, on June 7, 1982. She was Ph.D, educational technology, Nanjing Normal University, Nanjing, China, 2015. She is an associate professor, educational technology, School of Education Science, Nanjing Normal University, Nanjing, China.

L. Zhao, and S. Zhang, "Development of Visual Philosophy under Impact of Philosophy of Technology," Journal on Educational Technology, vol. 6, pp. 29-38, 2013. 